\title{
Benefit Sharing in Community Based Conservation Programs: The Case of Makao Wildlife Management Area, Tanzania
}

\author{
${ }^{1}$ Emmanuel B. Lwankomezi*, ${ }^{2} \mathrm{Dr}$ James Kisoza and ${ }^{2} \mathrm{Dr}$ Emmanuel Patrobas Mhache \\ ${ }^{1}$ St.Augustine University of Tanzania, ${ }^{2}$ Open University of Tanzania \\ *Corresponding author: emalwanko11@gmail.com
}

\begin{abstract}
Wildlife Management Area establishment around protected areas in Tanzania have been faced with various challenges including failures to adequately involve local populations in planning, governance and management of wildlife related resources. This study examined the benefit sharing mechanisms in Community Based Conservation programs, the case of Makao Wildlife Management Area in Meatu District, Tanzania. The study was conducted in Jinamo, Mwabagimu and Makao Villages. Data were collected from 281 heads of households using a survey design within the mixed approach. The study used simple random sampling based on the names of all heads of the households in each study village who were obtained from the village households as registered by village chairs. The major findings indicate that in the past five years, there is a considerable increase of income generated from wildlife investment in the study area which is used for payment of VGS salaries, food and other expense for VGS, community development and sharing among member villages. The study further shows that, inadequate involvement in the WMA activities results in local people having low perception on the WMA accrued benefits. The study recommends that it is essential to involve the local community in the WMA design and management in order to improve its acceptability and ownership. Benefit sharing in the WMAs should be designed as a strategy to offset conservation costs and build support for biodiversity conservation among conservation actors mainly local communities.
\end{abstract}

Keywords: Community Conservation, Benefit Sharing, Wildlife Management Areas

\section{Introduction}

Crop damage, livestock depletion, loss of human life, diseases and human-wildlife conflict are some of the major unprecedented development challenges facing communities bordering protected areas (Kideghesho, 2008; Redford et al., 2008; Songorwa 2015). Various scholars and environmental experts (Smyth, 2006; Taylor, 2006; UNESCO, 2005) have contended that among other factors, lack of proper benefit sharing scheme from wildlife and natural resource management among local people is one of the factors influencing the current anti-conservation activities resulting into threatening of wildlife conservation in protected areas. In a response, various reports and literature (Caro et al., 2003; Weladji et al., 2003; Pritchard, 2006; Underwood et al., 2009) have indicated that community wildlife conservation is a major scientific management and planning tool that helps solve social, economic, and environmental challenges facing protected areas. One of the goals of community wildlife conservation is to make sure communities participate in resource planning and management and gain financially from wildlife utilization (Smyth, 2006).

Protected areas are considered not only as a conservation tool, but also as a resource base to contribute to the reduction of poverty in many developing countries (Redford et al., 2008). Different players like international conservation groups, development partners and African governments mention local community participation as an imperative element in their programs despite having different approaches of what really constitutes participation and its role in conservation (McLaughlin, 2011). According to Kideghesho (2006), most of Community Based Natural Resources Managements (CBNRM) rely entirely on external finances for their development and sustenance; this diminishes the perceived value of the natural resources and detracts from local stewardship of the CBNRM processes when external finances come to an end. In some cases, inadequate government support has discouraged local 
communities from participating in wildlife conservation activities.

According to Redford et al., (2008) and BorriniFeyerabend et al., (2002), involving local community has been a prerequisite condition for the wildlife conservation to succeed. However, BorriniFeyerabend et al., (2004) notes that conservation costs are largely skewed towards local communities, hence no equitable benefits and costs. This notion has caused protected areas to be considered not only as a conservation tool but also as a resource base to contribute to the reduction of poverty among local communities in developing countries (Redford et al., 2008). Community incentives to conserve wildlife and the conditions they depend on vary at different times for different people (Makupa, 2013). Further, economic considerations need to be incorporated into community approaches to wildlife conservation to form a part of whether such approaches can be judged to have been successful in development and conservation terms. Kaswamila (2012) and Moyo, et al., (2016) identified initiatives that have been implemented that benefit local community including integrated conservation and development programmes, sharing tourism revenue generated from Protected Areas (PAs) such as entrance fees, provision of social services to adjacent communities, communities selling goods and services to tourists and employment opportunities.

According to Kideghesho (2008), benefit sharing is essential, but in itself might not be a satisfactory condition for communities to engage in wildlife conservation. Whether or not communities have economic incentives to conserve wildlife, and whether or not they are economically better off in the presence of wildlife, goes far beyond ensuring that a proportion of wildlife revenues are returned to them as broad development or social infrastructure benefits (Salafsky, 2011). It also depends on the economic costs that wildlife incurs, on the form in which wildlife benefits are received, on the costs and benefits of other economic activities which compete with wildlife and on a range of external factors which all limit the extent to which communities are able to appropriate wildlife benefits as real livelihood gains (Nelson, 2010).

Several literatures have found out that biodiversity conservation costs and benefits are not reasonably shared among different conservation actors (see Baldus, et al., 2003; Nelson, 2007; Moyo 2016). Adams and Hutton, (2007) indicate that benefits realized form conservation are global while conservation costs are borne by local people, predominantly poor and politically weak individuals in the community. For example, Songorwa (1999, 2015) found out that local community living next to protected areas lose more than half of their per capita income due to damage caused by wildlife. This means communities continue to bear the cost and become disempowered and marginalised in terms of natural resource management (Brockington et al., 2008). Most gains from biodiversity conservation are appropriated by the developed world, local elites and regional users of ecosystem services (Gereta, \& Røskaft, 2010).

In Tanzania, community based conservation is practiced through Wildlife Management Area which is an area of communal land set aside entirely as habitat for wildlife by member villages (URT, 2009). Wildlife management area is also a protected area set aside for the conservation of wildlife and for recreational activities involving wildlife (Kaswamila, 2012). To ensure that protected areas contribute in poverty reduction and in improving rural livelihoods, the government of Tanzania since 2003 has been promoting the establishment of Wildlife Management Areas (WMAs), a new protected area category under community management (URT, 2009 and Kaswamila, 2012). Makao is the newest WMA officially launched in 2007 and gazetted in 2009. Makao WMA covers $780 \mathrm{~km}^{2}$ and is comprised of 7 villages in the south-western Serengeti Ecosystem. Makao WMA is of highly importance to Tanzania's protected area as it acts as a wildlife corridor between Maswa Game Reserve, Ngorongoro conservation area and Serengeti National Park (URT, 2012). Therefore, findings of this study were expected to contribute insights on the possible ways of sharing benefits that are appropriate to allow full community participation in wildlife conservation and management. This study was guided by the following research questions:

1. What are the benefits attributed to Makao by the WMA?

2. What is the Perception of local communities on the WMA benefits?

3. What are the opportunities arising from introducing the WMA?

\section{Research Methodology}

This study employed the case study research design for collection and analysing of data in order to gain a deeper understanding of the situation in Makao WMA. Creswell, (2013) defines a case study as an 
empirical inquiry that investigates a contemporary phenomenon in depth and within its real-life context. This study employed a mixed method research approach, a form of research in which the researcher converges or merges quantitative and qualitative data in order to provide a comprehensive analysis of the research problem (Creswell, 2013).

This study used Slovins's (1960) formula to calculate an appropriate sample size from the total number of Households (945) to select 281 heads of households drawn from three villages namely Jinamo, Mwabagimu and Makao. This study used simple random sampling because each unit of the population has a known, equal, non-zero probability of being included in the sample (McNabb, 2002). The names of all heads of the households in each study village were obtained from the village households register maintained by village chairs. A random number generator was used to generate random numbers of households to be surveyed in each study village. Household heads were surveyed at each selected household on agreed time and date. The heads of households involved in this study had a role to play in Makao WMA.

\section{Statistical Treatment of Data}

Questionnaires were entered into the Statistical Package for Social Science (SPSS) version 21. Before that, responses were summarized into a number of different categories for entry into SPSS; the categories were identified after looking through the range of responses received from the respondents and then each response categories were assigned numbers. Before entering the information from the questionnaires into the SPSS, the code book was prepared. This gave the summary of the instruction that was used to convert the information that was obtained from each case into a format that SPSS can accept. To ensure uniformity in data entrance, a frequency run was carried out for all variables to verify any values that may have been entered incorrectly.

\section{Findings and Discussion}

This section presents the findings related to the benefits attributed to Makao WMA, the perception of local communities on the WMA benefits and the opportunities arising from introducing the WMA.

Research Question 1: What are the benefits attributed to Makao by the WMA?

Results in Table 1 shows that, Makao WMA income estimate for the past five years is Tsh 1,920,173,989. Results show a considerable increase of income over this period from Tsh 306,326,307.31 in 2015-2016 to $433,902,911$ in 2019-2020. This is attributed to fines and new terms in the renewed investment contract.

Table 1: Makao WMA revenues and expenses in TSH

\begin{tabular}{lllll}
\hline Financial Year & Reported Revenue & CBO Expenses & $\begin{array}{l}\text { Shared with } \\
\text { Member villages }\end{array}$ & $\begin{array}{l}\text { Revenue } \\
\text { by each village }\end{array}$ \\
\hline $2015-2016$ & $306,326,307.31$ & $246,201,307$ & $60,125,000.00$ & $8,589,285.714$ \\
$2016-2017$ & $381,319,502.80$ & $186,576,352$ & $131,743,150$ & $18,820,450$ \\
$2017-2018$ & $426,434,126.60$ & $329,621,626.60$ & $96,812,500$ & $13,830,357.14$ \\
$2018-2019$ & $372,191,141.04$ & $267,577,896$ & $104,613,245.00$ & $14,944,749.29$ \\
$2019-2020$ & $433,902,911$ & $315,477,911$ & $118,425.000 .00$ & $16,917,857.14$ \\
Total & $\mathbf{1 , 9 2 0 , 1 7 3 , 9 8 9}$ & $\mathbf{1 , 3 4 5 , 4 5 5 , 0 9 2 . 6 0}$ & $\mathbf{5 1 1 , 7 1 8 , 8 9 5}$ & $\mathbf{7 3 , 1 0 2 , 6 9 9 . 2 8}$ \\
\hline
\end{tabular}

Results further indicate that over the past 5 years, Tsh $511,718,895$ was shared with member villages, which is approximately Tsh 541,501.47 per household in five years corresponding to Tsh 13,168.27 approximately per person per year based on the 2012 census estimate of 7,772 (people residing in the Makao member villages). Further, data shows that, Tsh 1,345,455,092.60 was used for CBO expenses like payment of salaries, office expenses, administration and rule enforcement. Mwiba Holdings Company limited as an investor has contributed a total of Tsh 1,179,594,507 for the past five years which is equivalent to $61 \%$ of the total income generated from Makao WMA (Makao Financial Report, 2020).
During interview with a Makao Accountant, it was noted that, "Income generated from Investment company is used for payment of VGS salaries, food and other expense for VGS, community development and for sharing among member village."

Furthermore, results indicate that, the WMA has attained Tsh 110,989,400 in five years as an income from fines (Makao Financial Report, 2020).

These fines were paid by people who were caught grazing animals in the WMA. The fine was Tsh 10,000 per livestock which is equivalent to about 11,100 livestock caught grazing in the restricted areas. The highest fine payments were recorded during the financial year 2017/2018 when Tsh 
92,959,400 was reported (Makao Financial Report, 2020).

During interview with the Makao secretary, it was revealed that the operation to evict pastoralists from WMA was costly to Makao CBO as about Tsh $101,717,500$ was used for operation per diems, transport, fuel and veterinary services. This resulted to reduced amount of money shared among member villages. Makao chairman had this to say, "Makao CBO did not agree with funding the operation, we had to follow directives from DGO and District Commissioner for promise that the amount of money used will be refunded by the government."

Results show that, WMA through the Authorized Association was collecting non-consumptive utilization revenue direct from investors until 2012 when the revenue started to be collected by Wildlife division. This was after the introduction of the NonConsumptive Wildlife Utilization Regulations of 2008 (revised 2016). These new directives took power of revenue collection from the authorized association to central government. Regulation 16 (3) states that "the Director shall collect the fees prescribed under these regulations on behalf of the Authorized Association" (URT, 2012). In this study, the central government was frightened with total devolution of power to local community with fear of losing revenue.

WMA regulations Section 73 states that benefit sharing will be determined by circulars issued by government from time to time. For the proportion that the AA does capture, the Regulations state that at least $15 \%$ must be reinvested for resource development of the WMA. At least 50\% must be given to member villages in the WMA. At least $25 \%$ must be reinvested in strengthening the AA (URT 2012). Further, the sharing of wildlife related benefits are given in the Non-Consumptive Wildlife Utilization Regulation section 19 (b). This regulation states that, $5 \%$ shall be directed to the District Council, 25\% to the Director of Wildlife and $70 \%$ to Authorized Associations' (URT, 2012). WMA regulations also provide the directive of sharing income generated from resident hunting that; Authorized Association (40\%) and District Council 60\% (URT, 2012).

During focus group discussions with member villages, local community could not understand how benefit is shared. However, this was not surprising because of the recklessness of the system. While the sharing mechanism may be known, its determination is dependent on the benevolent of the central government (Kicheleri, et al., 2018; URT, 2012). For example, WMA regulation section 66 admits that benefit sharing will be determined by "circulars issued by government from time to time" (URT, 2012). The proportion that is captured by the AA, regulation states that, At least $15 \%$ must be reinvested for resource development of the WMA. At least $50 \%$ must be given to member villages in the WMA. At least $25 \%$ must be reinvested in strengthening the AA (URT, 2012). The Regulations offers a leeway for the individual AA to decide on the definite allocation within the above stipulated limits, this again jeopardize the ability of the community organization exercising their power.

However, from this narration of distribution of income, $10 \%$ of the revenue accrued by the $A A$ remains unaccountable (Moyo et al., 2016; URT, 2012). The current study could not establish how the proponents of the WMA regulation made this mistake on giving sharing modalities on only $90 \%$ of revenue captured by AA. It was however observed that, $A A$ is taking $60 \%$ and villages $40 \%$ which is against section 66 of the regulation which states that "Authorized Association shall ensure that (a) at least $15 \%$ of its annual gross revenue is re-invested for resource development; (b) at least $50 \%$ of its annual gross revenue is directed to villages forming part of the Wildlife Management Area; and (c) at least $25 \%$ of its annual gross revenue is used to strengthen the Authorized Association" (Makao Financial Report, 2020; URT, 2012).

This study found out that, villages received equal share from WMA investment which is about Tsh $14,620,539.86$ on average for the past five years (Makao Financial Report, 2020). During interview with conservation officials, there were no explanations from $A A, D G O$ and Wildlife division why villages had to be given equal amount of share despite villages having different settings. During focus group discussion, Makao village respondents could not agree with sharing of equal amount of benefits with other village. For example, one respondent from Makao village had this to say, "we advised for designing new sharing mechanism which will increase our share because we are the one providing large land compared to all villages forming the WMA". Further, local people reported that, some other village like Jinamo was less used as wildlife corridor and therefore had low economic value compared to Makao. 
Also during focus group discussions, respondents from Makao village insisted that, the village providing large area for conservation has to receive larger portion of benefit from WMA. This is a fact as from the WMA land use plan Makao village's area is as twice much as Mwabagimu and Jinamo combined. During interview with Makao village leader, the village executive director noted that, ".... It is not fair for Makao village to receive equal share of benefit from investors similar to other member village; the village providing large area for conservation has to receive larger portion of benefit from WMA."

The study found out that majority of local community were not aware of the amount of money paid to the village and could not understand the expenditure. This was revealed during the interview as one of respondents said "we don't know the amount of money paid to our village neither do we know the expenditure of the money given to our village." This implies that, while most of conservation efforts are channelled to inclusivity and community involvement, the implementation and the outcome of the same is not assumed. Again lack of information could be attributed to inadequate local involvement in village development plans. The involvement of local community in village planning is very important since it helps community ownership of conservation projects. The findings are similar to Kideghesho (2006) that the greatest potential for local gain from wildlife conservation is for the direct participation of landholders in wildlife decision-making which lies in the involvement of community members themselves as wildlife managers and entrepreneurs.

The study is in line with the findings by Makupa, (2013) who stated that the main intention of the
WMA is to provide incentive and promotion of local communities to participate in conservation, protection and devolution of wildlife resources management to communities by enhancing community benefit retentions. Similarly, Kisoza (2007) found out that community members bear the same notion of benefiting from wildlife management; however, the nature and kind of benefits realized is doubtful.

Research Question 2: What is the Perception of local communities on WMA benefits?

Study results indicate that wildlife management area is beneficial to local community as $66.5 \%$ percent was reported (see Table 2). Despite two third of respondents perceiving the WMA as beneficial to local community, about one third $(32.7 \%$ percent) responded in negation. Local community who indicated that WMA is beneficial must have been aware of community projects implemented in the village like schools, dispensaries and community houses built in the study villages.

Most of respondents in Table 2 perceived the WMA as beneficial to local community, while few respondents, responded in negation. This is due to the reason that, most of the communities consider tangible related benefits from wildlife resources. A review of Makao financial report and Makao annual reports revealed that there are no direct financial benefits directed to the household level. In most cases, WMA related benefits are intended to motivate people to align their behaviours with conservation goals. They also aim to reduce poverty, the main driving force triggering unsustainable activities through projects that benefit the village at large.

Table 2: Perceived WMA benefits to local communities

\begin{tabular}{lllll}
\hline \multirow{2}{*}{$\begin{array}{l}\text { Perception on WMA } \\
\text { Benefits }\end{array}$} & \multicolumn{4}{l}{ Frequency of respondents } \\
\cline { 2 - 5 } & $\begin{array}{l}\text { Makao } \\
(n=95)\end{array}$ & $\begin{array}{l}\text { Jinamo } \\
(n=91)\end{array}$ & $\begin{array}{l}\text { Mwabagimu } \\
(n=95)\end{array}$ & $\begin{array}{l}\text { Total } \\
(n=281)\end{array}$ \\
\hline Non Beneficial & $45(47.4 \%)$ & $14(15.4 \%)$ & $33(34.7 \%)$ & $92(32.7 \%)$ \\
Beneficial & $50(52.6 \%)$ & $77(84.6 \%)$ & $60(63.2 \%)$ & $187(66.5 \%)$ \\
\hline
\end{tabular}

Results in Figure 1 indicate that, benefit sharing in the study villages on average was fair as $40.13 \%$ percent was reported. Study results also shows that, on average $39.87 \%$ percent of respondents indicated that WMA benefit sharing was not fairly distributed among study villages. Particularly, $42.10 \%$ of respondents from Mwabagimu village indicate that sharing of benefit is not fair, $40.70 \%$ percent and $36.8 \%$ percent from Jinamo village and Makao village reported also reported so. About $20 \%$ percent of all respondents on average could not understand whether benefit sharing was fair or not. This could be attributed to local people inadequate involvement in WMA activities. 
During interview with Makao village leader, the village executive director noted that ".... It is not fair for Makao village to receive equal share of benefit from investor similar to other member villages; the village providing large area for conservation has to receive larger portion of benefit from WMA.

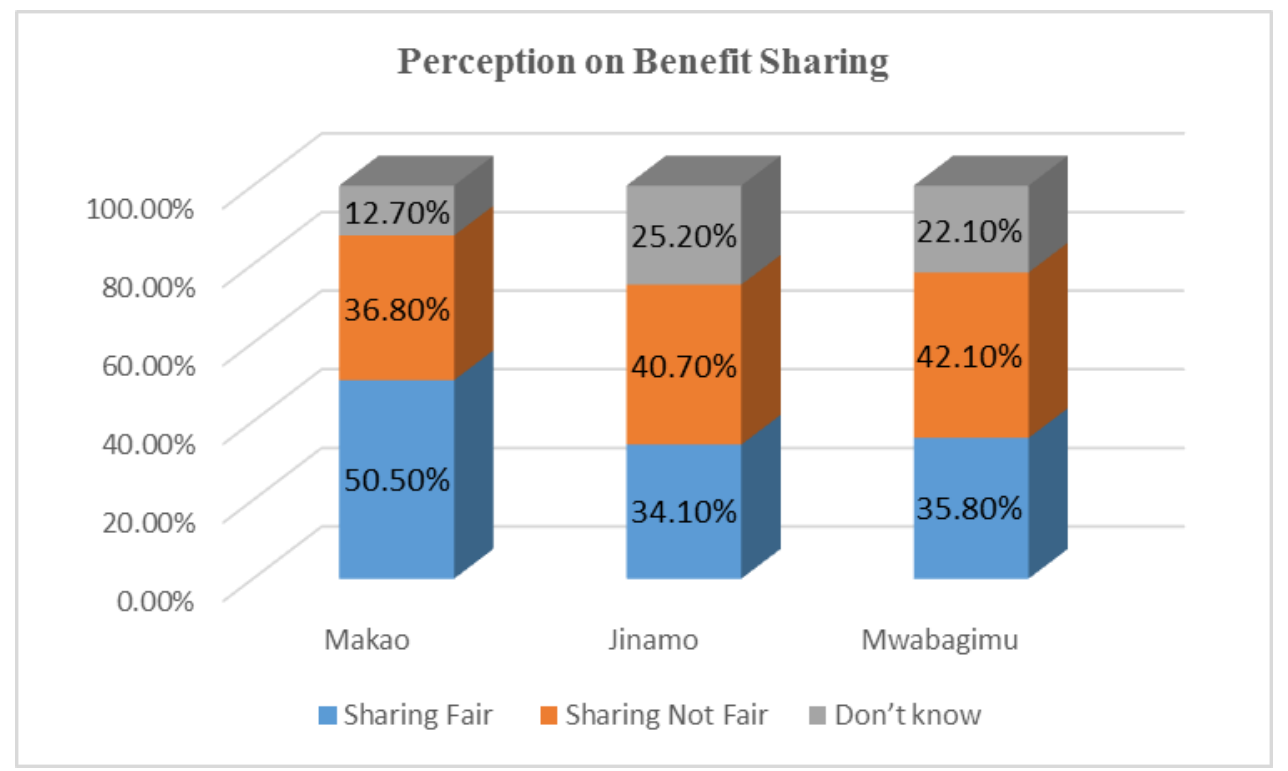

Figure 1: Pecieved Benefit sharing

The reason benefit sharing in the villages under investigation was perceived not fair was probably because communities were not involved in contract negotiations with investor and therefore could not understand the amount of money or any other related benefit paid by the investor.

Heads of households further revealed that the WMA income and share to member villages has greatly reduced requests from village leaders for the village development. For example, one revealed that the fund received from WMA have been invested in development projects such as maintenance and construction of secondary and primary school classrooms, village offices, health care centre and community services house. While income share among villages is very much appreciated, community members continued to view it as a ploy because of its inability to compensate for the forgone land.

During focus group discussions with heads of households, it was put forward that, local communities who received direct benefits from the WMA like employment were very much contented and were prepared to support the WMA development. For example, if you compare the level of WMA ownership among study villages, Makao village was the most contented with the benefit accrued from WMA (Figure 1). This was because Makao village was receiving addition of about 100 Million each year from the investor for land renting of Ngitili ranch and 26 million for community development (Makao Financial Report, 2020). One of the intentions of establishing the WMA was to help community access and manage wildlife related benefits (Mariki, 2015). This notion is highly supported especially when local communities are giving out their land for conservation of wildlife (Kicheleri, et al., (2018). Similarly, Brianne (2015) conducted a study on effect of community-based natural resource management on household welfare in Namibia and results indicated that the economic benefits derived from conservancies do not affect the wealth index of individual households.

The results further found out that most of conservation benefits were channelled to community level with no benefits or minimum benefits directed to local household. For example, one of respondents had this to say "we have never received any benefit (cash) from the WMA, what are we going to do with schools? Can you eat the school?" It was further observed that, projects like school buildings, dispensaries and water holes were constructed in prime areas which were seen as hindrance to communities on the edges of Makao WMA. Similar findings were noted by Makupa (2013) that poor distribution of benefits at the community level especial when physical structures are built in one part of the village threatened the sustainability of the Community Based Natural Resources Managements efforts.

Kaswamila (2012) conducted a study in Burunge Wildlife management area in Tanzania and found 
out that community attains benefits like the building of classrooms, village offices and other social services; nevertheless, community lacking capacity to influence authorized associations endangers benefits routed or realized at the household level compared with the participating village population. The results demonstrate that most local people would rather not be part of the WMA provided they do not benefit. This study is in line with Songorwa (1999) who reported that "the basic rule is that one participates if and when the program benefits him or her."

However, the study found out that despite the fact that local community realized less perceived benefits from the wildlife management area, their desire to protect and manage resources is high. During the interview, a village Leader from Jinamo said, "... conservation and protection of wildlife is our life, we will continue to protect our animals no matter what we get in return." These findings are supported by Kiss, (2004) and Kaswamila, (2012) that local people living in natural resources areas have a bigger interest in the sustainable use of natural resources than centralized or distant government or private management institutions. Mariki (2015) assessed the impact of conservation on local communities and the reaction of local communities towards conservation around the Enduimet Wildlife Management Area. Results show that wildlife management areas benefit-based models are based on partial understanding of the economics of community conservation and of the nature of wildlife benefits.

Research Question 3: What are the opportunities arising from introducing the WMA?

Results in Table 3 indicate that, $29.2 \%$ percent of all respondents reported employment as an opportunity arising from the WMA in the study area. The highest employment opportunities were reported in Makao village by $47.4 \%$ of respondents. About $23.8 \%$ percent of all respondents identified Small business as an opportunity arising from the WMA in the study area. The highest percentage (29.5\%) of local people engaging in small business was found in Mwabagimu village followed by Jinamo Village (26.4\%).

Results in Table 3 further indicate that, $17.8 \%$ were practicing cash crops farming. At village levels, there were variations on respondents' perception with regards to cash crop farming. In Makao village, only $10.5 \%$ of respondents reported the same whereas in Mwabagimu village, a pastoralist village, about $18.9 \%$ reported practicing cash crop farming and in Jinamo village $24.2 \%$ of respondents reported practicing cash crop farming. The varied responses could be attributed to the high level market integration of farmers in the study villages.

Table 3: Income generating activities brought by WMA

\begin{tabular}{lcccc}
\hline Income generating & \multicolumn{3}{c}{ Frequency of respondents } & Total \\
& Makao (n=95) & Jinamo (n=91) & Mwabagimu & \\
& & & $(\mathbf{N = 9 5 )}$ & (N=281) \\
\hline None & $5(5.3 \%)$ & $3(3.3 \%)$ & $3(3.2 \%)$ & $11(3.9 \%)$ \\
Cash crop farming & $10(10.5 \%)$ & $22(24.2 \%)$ & $18(18.9 \%)$ & $50(17.8 \%)$ \\
Food crop production & $13(13.7 \%)$ & $11(12.1 \%)$ & $16(16.8 \%)$ & $40(14.2 \%)$ \\
Small business & $15(15.8 \%)$ & $24(26.4 \%)$ & $28(29.5 \%)$ & $67(23.8 \%)$ \\
Wage employment & $45(47.4 \%)$ & $17(18.7 \%)$ & $20(21.1 \%)$ & $82(29.2 \%)$ \\
Handcrafts for sale & $3(3.2 \%)$ & $2(2.2 \%)$ & $1(1.1 \%)$ & $6(2.1 \%)$ \\
Water Vending & $1(1.1 \%)$ & $9(9.9 \%)$ & $6(6.3 \%)$ & $16(5.7 \%)$ \\
Tourism Guide & $2(2.1 \%)$ & $2(2.2 \%)$ & $2(2.1 \%)$ & $6(2.1 \%)$ \\
Other & $1(1.1 \%)$ & $1(1.1 \%)$ & $1(1.1 \%)$ & $3(1.1 \%)$ \\
\hline
\end{tabular}

Key: Percentages in some columns are not totaling to 100 because of missing data

Study results indicate that responses on the income generating activities arising from Makao WMA varied among villages. For example, In Makao village, respondents identified employment opportunities as the major income generating activities by $47.4 \%$ percent while Jinamo and Mwabagimu village identified small business as a major income generating activities by $26.4 \%$ and $29.5 \%$ percent respectively.
Findings in Table 3 show that some community members had secured job opportunities from tourist investors in Makao WMA; other community members had opportunity to sell crops and conduct small businesses.

Interview with village leaders shows that local community members were contented that Makao WMA has brought direct employment. This was because most of the community members were 
employed in tourism related activities while others were employed as village game scouts (VGS). While community members perceived an increase of employment opportunities compared to before the establishment of the Makao WMA, just a few individuals had an opportunity to secure employment from tourist investors in Makao WMA as most employment opportunities were taken by people from outside.

One of respondents said, "Employment is provided to either the daughter/ sons of our leaders or to outsiders not coming from Makao WMA forming villages." This is in line with the study findings by Makupa (2013) which revealed that those few who secured jobs and their relatives were the only members of the community who perceived direct benefits from the wildlife. Most of local community members complained about investors employing few people from the study area. This notion of few community members securing employment in conservation related activities created few local elites who pocket significant share of the conservation income that would otherwise be used for community development (Makupa, 2013 and Moyo et al., 2016).

Furthermore, in assessing the employment status in the study area, results in table 4 show that, while $60 \%$ and $54.7 \%$ of respondent in Makao and Mwabagimu villages respectively reported to understand procedures used for employment, only $39.6 \%$ percent of the respondents in Jinamo village understood employment procedures. This could be attributed to community low participation in the WMA management.

Table 4: Local Understand on employment procedures

\begin{tabular}{lllll}
\hline $\begin{array}{l}\text { Understanding } \\
\text { Employment } \\
\text { procedure }\end{array}$ & \multicolumn{4}{l}{ Frequency of respondents } \\
\cline { 2 - 5 } & Makao & Jinamo & Mwabagimu & Total \\
& & & & \\
& $(\mathrm{n}=95)$ & $(\mathrm{n}=91)$ & $43(45.3 \%)$ & $136(48.4 \%)$ \\
No & $38(40.0 \%)$ & $55(60.4 \%)$ & $52(54.7 \%)$ & $145(51.6 \%)$ \\
\hline
\end{tabular}

Key -Numbers in brackets are Valid Percentages

The identification of the opportunities arising from introducing the Makao WMA was tricky because some of these activities were practiced prior to gazzetment. However, communities which had been practicing crop farming were of the opinion that production of crops has increased tremendously after the Makao WMA gazetment. It was also revealed that villages owned considerable pieces of land even after some of their land were taken to satisfy the need for the wildlife conservation. Most of the crops grown included Maize, sorghum, sun flower and millet. These crops were sold to neighbour villages, towns and visitors in the village.

During the focus group discussion, respondents revealed that, their life had been improved by selling farm produces which reduced the burden on the wildlife and was used as an alternative for improving their socio-economic conditions. One of respondents from Mwabagimu village had this to say, "Crop production has really improved our living standard, we sell and get some money which is used to cater for our needs, hence reducing dependence on wildlife." This is in line with findings of Kideghesho (2008) and Kaswamila (2012) who argued that the main intention of community conservation is to promote diversification of income and creation of alternative income sources to local community in order to improve their livelihoods.

\section{Conclusions and Recommendations}

There is a considerable increase of income generated from wildlife investment in the study area for the past five years, which is used for payment of VGS salaries, food and other expense for VGS, community development and sharing among member villages.

Local community perceived the current WMA benefits to be insufficient to offset the wildlifeinduced costs and opportunity costs of conservation. Further, there were no direct financial benefits directed to the household level. This was because most of the communities considered tangible/direct gains as the only benefits from the wildlife resources. However, study results identified other opportunities arising from introducing the WMA as cash crop farming, food crop production, small business, wage employment, water vending, tourism guide and handcrafts for sale.

Therefore, benefit sharing in the WMA should be designed as a strategy to offset conservation costs and build support for biodiversity conservation among conservation actors mainly local communities. It also recommends that there should 
be a proper community involvement in planning and management of the wildlife related resources in order for the local people to own and support conservation efforts. There is need for integration of the local community related activities in the wildlife management in order to empower the diversification of economy around protected areas.

\section{Reference}

Adams, W.M. \& Hutton, J. (2007). People, parks and poverty: Political ecology and biodiversity conservation. Conservation and Society, 5(2):147-183.

Baldus, R., B. Kibonde, and L. Siege. (2003). Seeking conservation partnership in the Selous Game Reserve, Tanzania. Parks 13:50-61.

Brianne Riehl, Hisham Zerriffi, and Robin Naidoo (2015) Effects of CommunityBased Natural Resource Management on Household Welfare in Namibia. PLOS, Open access journal e0125531. https://www.ncbi.nlm.nih.gov/pmc/article s/PMC4429124/. Retrieved on 20/1/2020

Borrini-Feyerabend, G., Banuri, T., Farvar, T., Miller, K., \& Philips, A. (2002). Indigenous and local communities and protected areas: Rethinking the relationship. Parks, 12, 515.

Brockington, D., Duffy, R. \& Igoe, J. (2008). Nature unbound: Conservation, capitalism, and the future of protected areas. London: Earthscan.

Caro, T., Mulder, M. and Moove, M. (2003). Effects of conservation education on reasons to conserve biological diversity. Biological Conservation, 114, 143-152.

Creswell, J.W. (2013). Research design: Qualitative, quantitative, and mixed methods approaches $\left(4^{\text {th }}\right.$ Ed). Sage Publication, London.

Gereta, Emmanuel J, and Eivin Roskaft (2010) Conservation of Natural Resources, some Africa and Asia Examples. Tapir Academic Press. No-7005 Trondheim, Norway.

Kaswamila, A.L. (2012). An analysis of the contribution of community wildlife management areas on livelihood in Tanzania. Retrieved on July 12, 2018, http://cdn.intechopen.com/pdfs/25746/In TechAn analysis of the contribution of community wildlife management areas on livelihood in tanzania.pdf
Kideghesho, J.R. (2006). Wildlife conservation and local land use conflicts in Western Serengeti corridor, Tanzania. PhD thesis of Norwegian University of Science and Technology, Faculty of Natural Science and Technology.

Kideghesho, J.R. (2008). Co-existence between the traditional societies and wildlife in western Serengeti, Tanzania: Its relevancy in contemporary wildlife conservation efforts. Biodiversity Conservation, 17: 1861-1881

Kisoza L. J. A. (2007) The Role of Local Institutions in the Management of Agro-Pastoral and Pastoral Systems: A Case Study of Mkata Plains, Kilosa District and Ngorongoro Conservation Area, Ngorongoro District, Tanzania. A Thesis Submitted in fulfillment of the Requirements for the Degree of Doctor of Philosophy of the Sokoine University of Agriculture

Kiss, A. (2004). Making biodiversity conservation a land-use priority. In T.O. McShane \& M.P. Wells (Eds.), Getting biodiversity projects to work: Towards more effective conservation and development (pp. 98123). New York: Columbia University Press. Kicheleri R. P. Thorsten T., Martin R. N., Kajembe G. C., Mombo F. M., (2018) Power Struggles in the Management of Wildlife Resources: The Case of Burunge Wildlife Management Area, Tanzania Journal of Environment \& Development. 2018:1-15.

Makupa. E. E. (2013) Conservation efforts and local livelihoods in Western Serengeti, Tanzania: Experiences from Ikona Community Wildlife Management Area. A Dissertation Submitted in Partial Fulfillment of the Requirements for the degree of doctor of philosophy in the Department of Geography University of Victoria.

Mariki. S. B., (2015) Communities and conservation in West Kilimanjaro, Tanzania: Participation, costs and benefits, Doctor (PhD) Thesis. Department of International Environment and Development (Noragric) Norwegian University of Life Sciences

Makao Financial Report (2020). The Makao wildlife management area income and expenditure report for conservation and development activities for the year 20152020, issued in September 2020. 
McLaughlin, C.M. (2011). People living in protected areas: A comparative study of the social impacts of conservation in Latin America"s Mamirauá Sustainable Development Reserve and Ría Celestún biosphere reserve. MA Thesis. United Nations" University for Peace, USA

McNabb, David E (2002), Research Methods in Public Administration and Non Profit Management, Quantitative and Qualitative Approaches, Armonk, New York, M E Sharpe.

Moyo, F., J. ljumba, and J. F. Lund. (2016). Failure by design? Revisiting Tanzania's flagship Wildlife Management Area Burunge. Conservation and Society 14:232-242.

Nelson, F. (2007). Emergent or illusory? Community wildlife management in Tanzania. IIED, Issue paper no. 146. Nottingham, UK: Russell Press Nelson F, Blomley T. (2010). Peasants' forests and the King's game? Institutional divergence and convergence in Tanzania's forestry and wildlife sectors. Pages 79-105 in F Nelson, editor. Community rights, conservation and contested land. Earthscan, London.

Pritchard T. (2006) Environmental Education. Its Social Relevance in North West Europe Council of Europe Unpublished Report CE / May/ (68 / 67) Strasbourg.

Redford, K.H., Levy, M.A., Sanderson, E.W. \& de Sherbinin, A. (2008). What is the role for conservation organizations in poverty alleviation in the world's wild places? Oryx, 42:516-528.

Salafsky, N. (2011). Integrating development with conservation: A means to a conservation end, or a mean end to conservation? Biological Conservation, 144: 973-978.

Smyth, J.C. (2006) Environment and education: a view of a changing scene, Environmental Education Research 12(3,4):247-264.
Slovin, E. (1960) Slovin's formula for sampling technique.

https:www.jobmer.org/2020/jobmer_vol4_i ssue2_article7\%20full\%20text.pdf.

Retrieved on 15/3/2021.

Songorwa, A.T. (1999). Community-based wildlife management (CWM) in Tanzania: Are the communities interested? World Development, 27(12): 2061-2079.

Songorwa AN (2015) Sustaining wildlife conservation in growing socio-economic demands: Can the elephant in Tanzania survive the current wave of poaching? The 10th TAWIRI Biennial Scientific Conference December 2-5, 2015 Arusha, Tanzania

Taylor, R.D. (2006). Case study: Communal Areas Management Programme for Indigenous Resources (CAMPFIRE) Zimbabwe. Prepared for the USAID=FRAME project: case studies on successful southern African NRM initiatives and their impacts on poverty and governance. IUCN, SOUTH Africa, Pretoria.

Underwood, E., Klausmeyer, K., Morrison, S., Bode, M. and Shaw, M. (2009). Evaluating conservation spending for species return: a retrospective analysis in California. Conservation Letters, Sage Publication, Calfornia.

UNESCO (2005). United Nations Conference on the Environment and Development: Agenda 21. Tech. rep., UNESCO.

URT (2009). United Republic of Tanzania. The Wildlife Conservation Act of 2009

URT (2012). United Republic of Tanzania: Ministry of Natural Resources and Tourism: Wildlife Conservation (Wildlife Management Areas) Regulations of 2012.

Weladji, R.B. \& Tchamba, M.N. (2003). Conflict between people and protected areas within the Be'noue Wildlife Conservation Area, North Cameroon. Oryx, 37(1):72-79. 